\title{
Monoclonal antibodies to a 16-kDa antigen of Serpulina (Treponema) hyodysenteriae
}

\author{
W. THOMAS and R. SELLWOOD* \\ AFRC Institute for Animal Health, Compton, Berks RG16 ONN
}

\begin{abstract}
Summary. Monoclonal antibodies (MAbs) were produced to an outer-envelope preparation from Serpulina (Treponema) hyodysenteriae, the aetiological agent of swine dysentery. Three MAbs (isotype IgG1) were obtained. All three recognised a $16-\mathrm{kDa}$ antigen that was common to most strains of $S$. hyodysenteriae of different serotypes but was absent from nonpathogenic, porcine intestinal spirochaetes. Immunofluorescence and immunogold labelling studies showed that the $16-\mathrm{kDa}$ antigen was exposed on the surface of intact spirochaetes. The MAbs agglutinated freshly grown cultures of spirochaetes and inhibited growth of $S$. hyodysenteriae strains in vitro.
\end{abstract}

\section{Introduction}

The causative organism of swine dysentery is Treponema hyodysenteriae, ${ }^{1}$ which has recently been renamed Serpula hyodysenteriae. ${ }^{2}$ However, since this genus name is used to designate a fungal genus there has been a further proposal that the name Serpulina should be adopted. ${ }^{3}$

The immune response of pigs to antigens of $S$. hyodysenteriae has usually been investigated in pigs with swine dysentery ${ }^{1,4-8}$ or in convalescent pigs. ${ }^{9,10}$ Attempts have been made to correlate immunity to swine dysentery with the presence of serum antibody. These investigations have demonstrated that an immune response to the lipopolysaccharide (LPS) antigens of strains of $S$. hyodysenteriae leads to protection. However, it has been shown that the protection afforded by the immune response to LPS is serotype specific both in the mouse model ${ }^{11}$ and in pigs. ${ }^{6,10}$ Polypeptide antigens have also been investigated to identify antigens which may give rise to a protective immune response. ${ }^{12-16}$ However, only one polypeptide antigen with this property has been identified. Polyclonal antibodies raised against the outer envelope of the spirochaete have been shown to inhibit growth in vitro. ${ }^{16}$ This activity was attributed to antibodies directed against one antigen of $16 \mathrm{kDa}$.

The purpose of this study was to investigate the properties of this antigen by the production and use of monoclonal antibodies (MAbs) prepared against the outer envelope of one strain of $S$. hyodysenteriae (VS1).

\section{Materials and methods}

\section{Bacterial strains}

$S$. hyodysenteriae strains used in this investigation were isolated either from the faeces of pigs with swine dysentery (B234, serotype 1; B204, serotype 2; S75/1, serotype 2; B169, serotype 3; P18A, serotype 4; MLC52/80, serotype 7; LL6 and P35/2, serotype not designated) or from normal animals (VS1, serotype 6) as described previously. ${ }^{16,17}$ Other non-pathogenic intestinal spirochaetes, M1, PWS/A and $S$. innocens strains B256 and 4/71 were also tested. The spirochaete strains were cultured under anaerobic conditions $\left(\mathrm{N}_{2}\right.$ $\left.95 \%, \mathrm{CO}_{2} 5 \%\right) .{ }^{17}$ Culture tubes containing $2 \mathrm{ml}$ of trypticase soya broth (TSB) supplemented with rabbit serum $10 \%$ were prepared under anaerobic conditions and inoculated from frozen stock cultures. After incubation at $37^{\circ} \mathrm{C}$ for $2-4$ days these primary cultures were used to inoculate $500-\mathrm{ml}$ bottles containing $50 \mathrm{ml}$ of the above medium under an anaerobic atmosphere. Following incubation for a further 2-4 days, when the cell density was $10^{7}-10^{8} / \mathrm{ml}$, the spirochaetes were harvested.

\section{Preparation of outer envelopes}

Outer envelopes of $S$. hyodysenteriae strain VS1 were extracted with sodium dodecyl sulphate (SDS) $0.005 \% \mathrm{w} / \mathrm{v}$ as described previously ${ }^{16}$ and dialysed extensively against several changes of distilled water.

\section{Enzyme-linked immunosorbent assay (ELISA)}

The outer envelope preparation of strain VS1 was diluted in coating buffer $\left(15 \mathrm{mM} \mathrm{Na} \mathrm{Na}_{2}, 35 \mathrm{~mm}\right.$ $\mathrm{NaHCO}_{3}$ ) to a protein concentration of $1.45 \mu \mathrm{g} / \mathrm{ml}$. 
Each well on a 96-well microtitration plate was coated with $100 \mu \mathrm{l}$ of this preparation. After incubation at $4^{\circ} \mathrm{C}$ for $18 \mathrm{~h}$ the plate was washed three times in phosphate-buffered saline (PBS; $0.17 \mathrm{M} \mathrm{NaCl}, 3.35 \mathrm{mM}$ $\mathrm{KCl}, 0.01 \mathrm{M} \mathrm{Na} \mathrm{HPO}_{4}, 1.84 \mathrm{mM} \mathrm{KH} \mathrm{KO}_{4}, \mathrm{pH} \mathrm{7.2)}$ containing Tween $200.01 \% \mathrm{v} / \mathrm{v}$, then the plate was blotted dry. Diluted antiserum or culture fluid (100 $\mu \mathrm{l})$ was added to each well and the plate was incubated at room temperature for $2 \mathrm{~h}$, then rinsed as above. Rabbit anti-mouse immunoglobulin conjugated with horseradish peroxidase (Nordic) was diluted 1 in 10000 in fetal calf serum (FCS) $10 \%$ and $100 \mu \mathrm{l}$ was added to each well. The plates were incubated at room temperature for a further $2 \mathrm{~h}$ before the wells were washed with rinsing buffer. A solution of horseradish peroxidase substrate $\left(3,3^{\prime}, 5,5^{\prime}\right.$ tetramethyl benzidine; ICN) $0.01 \%$, dimethyl sulphoxide $1 \%, \mathrm{H}_{2} \mathrm{O}_{2} 0.045 \%$ in $0.1 \mathrm{M}$ sodium acetate ( $\mathrm{pH} \mathrm{6.0)}$ was added to each well (100 $\mu \mathrm{l} /$ well). After $10 \mathrm{~min}$, an intense blue colour developed in positive wells. The reaction was stopped by the addition of $25 \mu \mathrm{l}$ of $2 \mathrm{M} \mathrm{H}_{2} \mathrm{SO}_{4}$ to each well and the optical density was measured at $450 \mathrm{~nm}$ on an ELISA plate reader (Titertek Multiskan MCC; Flow Laboratories).

\section{Production of monoclonal antibodies}

MAbs were prepared by a method similar to that described by Howard et al. ${ }^{18}$ Four BALB/c mice were inoculated intraperitoneally with $0.2 \mathrm{ml}$ of an outerenvelope preparation of $S$. hyodysenteriae strain VS1 in Freund's complete adjuvant (protein content $25 \mu \mathrm{g} / \mathrm{ml}$ ). A further intraperitoneal inoculation in Freund's incomplete adjuvant was given 5 weeks later and 2 weeks after that a serum sample was obtained from each mouse. The serum antibody titre of each mouse was determined by ELISA and the mouse with the highest serum antibody titre was selected for MAb production. A pre-fusion intramuscular boost of antigen ( $20 \mu \mathrm{g}$ in $200 \mu \mathrm{l}$ of saline) was given to that mouse 13 weeks after the initial inoculation. This was followed by an intraperitoneal inoculation 2 days later ( $50 \mu \mathrm{g}$ of antigen in $500 \mu \mathrm{l}$ of saline). The fusion procedure was performed $24 \mathrm{~h}$ after this final boost. Cells from the spleen of the hyperimmunised mouse and actively growing cells of the mouse myeloma cell line NS1 were combined in suspension and then centrifuged. Fusion was achieved by agitation of the mixed cells in $1 \mathrm{ml}$ of pre-warmed polyethyleneglycol. Hybridomas were selected by growing the fused cells in RPMI 8 medium (Gibco) containing $\mathrm{NaHCO}_{3} 0 \cdot 22 \%$ $\mathrm{w} / \mathrm{v}, \mathrm{FCS} 10 \% \mathrm{v} / \mathrm{v}, 0.02 \mathrm{~mm}$ L-glutamine, penicillin 50 units $/ \mathrm{ml}$, streptomycin $50 \mu \mathrm{g} / \mathrm{ml}, 12.5 \mathrm{mM} \mathrm{NaOH}$, $0.1 \mathrm{~mm}$ hypoxanthine, $0.4 \mu \mathrm{M}$ aminopterin and $16 \mu \mathrm{M}$ thymidine (HAT) which does not permit the continued growth of unfused myeloma cells.

The fused cells were dispensed into cluster plate wells over a feeder layer of mouse peritoneal macrophages. After incubation for 10 days at $37^{\circ} \mathrm{C}$, the antibody in the fluid from each of the wells was assayed by ELISA. The individual colonies of cells in wells with antibody were isolated in fresh cluster wells. Colonies that were positive in the ELISA on second antibody screen were either frozen in gaseous phase nitrogen or cloned by limiting dilution. After two cloning steps the hybridomas were considered to be monoclonal.

Ascitic fluid was prepared by growing the hybridoma cells in $40-\mathrm{ml}$ flask cultures to $60 \%$ confluence, and then the cells were harvested by centrifugation. The cells were resuspended to a density of $5 \times 10^{6}$ cells $/ \mathrm{ml}$ in saline. This suspension $(0.5 \mathrm{ml})$ was injected intraperitoneally into each of $10 \mathrm{BALB} / \mathrm{c}$ mice that had been sensitised by an intraperitoneal injection of $0.5 \mathrm{ml}$ of 2,6,10,14-tetramethyl pentadecane. The cells were allowed to grow for 10 days before the mice were killed and the ascitic fluid was collected.

Isotyping of the MAbs was performed, according to the manufacturers instructions, with the MMt RC1 kit (Serotec).

\section{SDS-PAGE and Western blotting}

Polypeptides were separated by SDS-PAGE ${ }^{19}$ on polyacrylamide $12.5 \% \mathrm{w} / \mathrm{v}$ gels at $35 \mathrm{~V}$ for $18 \mathrm{~h}$. The polypeptides were transferred electrophoretically to nitrocellulose at $70 \mathrm{~V}$ for $18 \mathrm{~h}^{20}$ and Western blotting of the nitrocellulose filters was done as described previously ${ }^{17}$ with monoclonal hybridoma cell supernatant fluid diluted 1 in 5 in FCS $20 \%$. The polypeptides that bound antibodies were identified by ${ }^{125} \mathrm{I}$ protein A (Amersham) labelling and autoradiography with X-ray film (Fuji) at $-70^{\circ} \mathrm{C}$ with enhancing screens.

\section{Slide agglutination and growth inhibition tests}

Cultures of 13 porcine spirochaete strains were grown in 50-ml volumes of TSB under anaerobic conditions for $48 \mathrm{~h}$. The cells were harvested and washed three times in PBS. A drop of each suspension was mixed with $10 \mu$ l of ascitic fluid from the three monoclonal cell lines on a glass slide. The preparations were observed over 2 min for macroscopic agglutination then examined microscopically.

The effect of three MAbs on the growth of 13 spirochaete strains was estimated by the growth inhibition test. ${ }^{21}$ The spirochaetes were grown to a cell density of $10^{7}-10^{8}$ cells $/ \mathrm{ml}$. Trypticase soya agar (TSA) plates were inoculated with $0.5 \mathrm{ml}$ of bacterial cultures either undiluted or diluted 1 in 10 or 1 in 100 . The culture fluid was allowed to soak into the agar for a few minutes, then the excess liquid was removed. Serum or ascitic fluid $(20 \mu \mathrm{l})$ was applied to the surface of $3 \mathrm{M}$ filter disks (Whatman). In order to compare the effectiveness of the three MAbs, the ascitic fluids were diluted to equivalent antibody titres as determined by ELISA. The disks with ascitic fluid or antibody were placed on the surface of the inoculated agar. The plates 


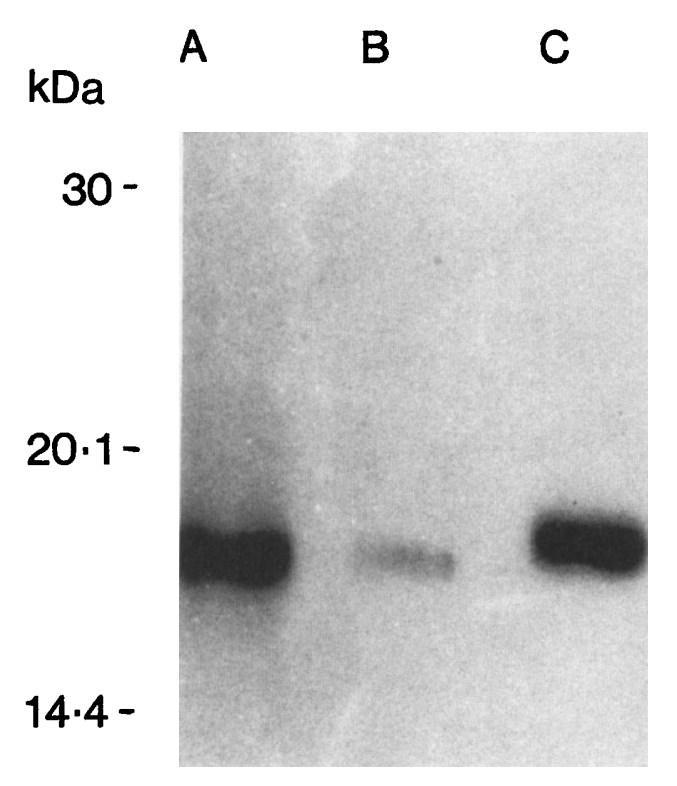

Fig. 1. Immunoblot of $S$. hyodysenteriae strain VS1 probed with MAbs AC4 (lane A), EB4 (B) and FC2 (C).

were incubated anaerobically $\left(\mathrm{CO}_{2} 5 \%, \mathrm{~N}_{2} 95 \%\right)$ at room temperature for $18 \mathrm{~h}$ to allow the antibody to diffuse into the agar before further incubation at $37^{\circ} \mathrm{C}$ under anaerobic conditions for 3-5 days. Zones of growth inhibition were then measured.

\section{Immunogold labelling}

Cultures of spirochaete strains P18A, VS1 and PWS/A were cultured in $50 \mathrm{ml}$ of TSB to a density of $10^{7}-10^{8}$ cells $/ \mathrm{ml}$. The cells were centrifuged at $10000 \mathrm{~g}$ for $1 \mathrm{~min}$ then washed three times in PBS. A drop of bacterial cell suspension was placed on a pallet of dental wax. Graphite-coated nickel grids (300 space) were placed face down on the surface of the drops for $30 \mathrm{~s}$. The grids were gently blotted dry and immersed in undiluted MAb F325 AC4 culture supernate. After $1 \mathrm{~h}$, the grids were gently rinsed in PBS, immersed in one drop of goat anti-mouse $10 \mathrm{~nm}$ gold conjugate (Agar Scientific), diluted 1 in 10 in PBS, for $1 \mathrm{~min}$ and then in a second drop for $30 \mathrm{~min}$. The unbound gold conjugate particles were removed by rinsing twice in PBS and once in distilled water. The grids were negatively stained in phosphotungstic acid $2 \%$ for $20 \mathrm{~s}$, then dried and examined in a Philips EM 300 electronmicroscope at an accelerating voltage of $80 \mathrm{kV}$.

\section{Immunofluorescent labelling}

Cultures of 13 porcine spirochaete isolates were grown for $48 \mathrm{~h}$, the cells were then harvested and washed three times in PBS. A small volume $(2 \mathrm{ml})$ of the individual cell suspensions was centrifuged $(10000 \mathrm{~g}, 1 \mathrm{~min})$ and each pellet of cells was resuspended in $100 \mu \mathrm{l}$ of MAb F325 AC4 ascitic fluid diluted in PBS. The cells were incubated with the primary antibody for $2 \mathrm{~h}$ at $4{ }^{\circ} \mathrm{C}$, washed three times in PBS and then labelled with $100 \mu$ l of rabbit anti-mouse FITC conjugate (Nordic), diluted 1 in 50 in PBS, for $1 \mathrm{~h}$ at $4^{\circ} \mathrm{C}$. Thereafter the cells were washed three times with PBS, resuspended in a mixture of PBS and glycerol $(1: 1)$ and examined by fluorescent microscopy.

\section{Results}

\section{Monoclonal antibodies}

Fusion 325, with the spleen cells from a single mouse, yielded three hybridomas that produced antibody to outer-envelope antigens as determined by ELISA. These MAbs were designated AC4, EB4, and FC2; all were of isotype IgG1.

\section{Western blotting}

The three MAbs AC4, EB4 and FC2 developed from the outer-envelope antigens of strain VS1 recognised a single band of $16 \mathrm{kDa}$ (fig. 1). Although similar ELISA antibody titres were obtained for all three

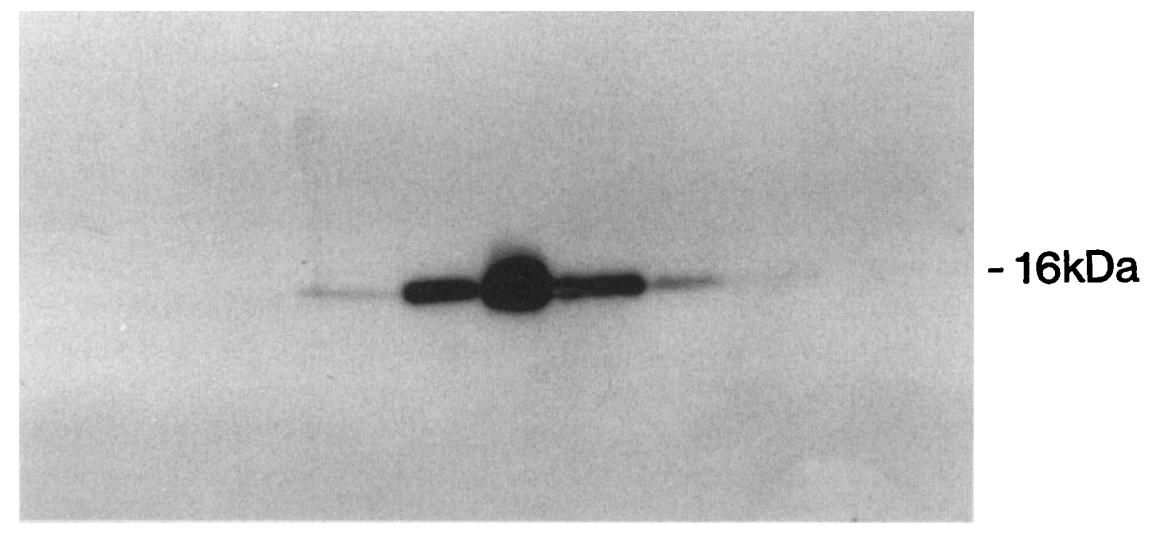

\section{$\begin{array}{lllllllllllll}A & B & C & D & E & F & G & H & \text { I } & J & K & L\end{array}$}


Table. Comparison of the agglutination and immunofluorescence of $S$. hyodysenteriae strains and non-pathogenic intestinal spirochaetes by MAb AC4 and the inhibition of growth by the MAbs AC4, EB4 and FC2

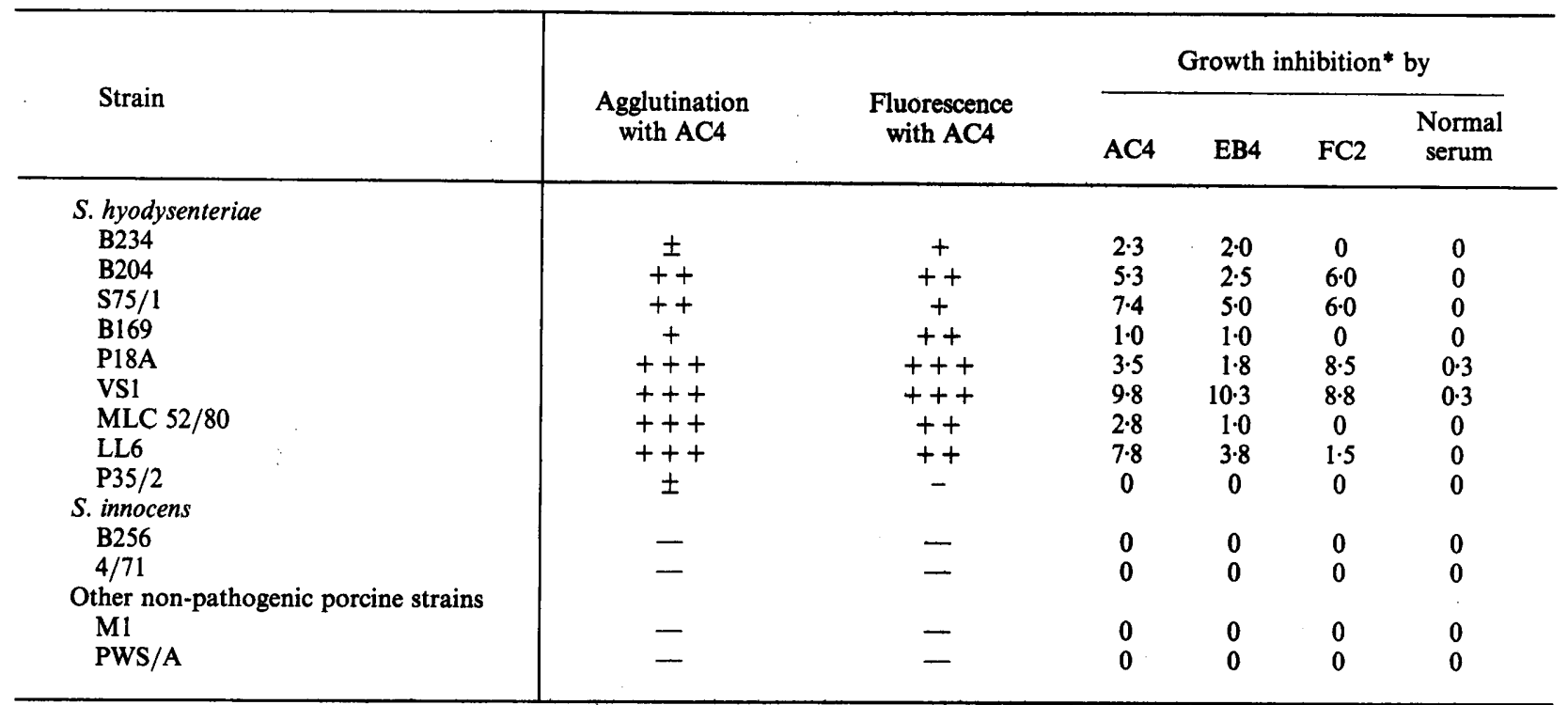

- , No fluorescence or agglutination; \pm , fluorescence just detectable or weak microscopic agglutination; + , weak fluorescence or microscopic agglutination; ++ , average fluorescence or weak macroscopic agglutination; +++ , good fluorescence or strong macroscopic agglutination.

* Mean of two measurements of the widths of the zones of growth inhibition (mm).

MAbs, AC4 and FC2 reacted more strongly than EB4. All three antibodies also reacted with most of the strains of $S$. hyodysenteriae examined but failed to recognise a band in the preparations of nonpathogenic spirochaetes B256, M1, PWS/A and 4/71 (fig. 2). The intensity of the labelling after immunoblotting varied between the $S$. hyodysenteriae strains. Strains P18A, VS1 and LL6 were strongly labelled, whereas B204, S75/1 and MLC52/80 were less in-

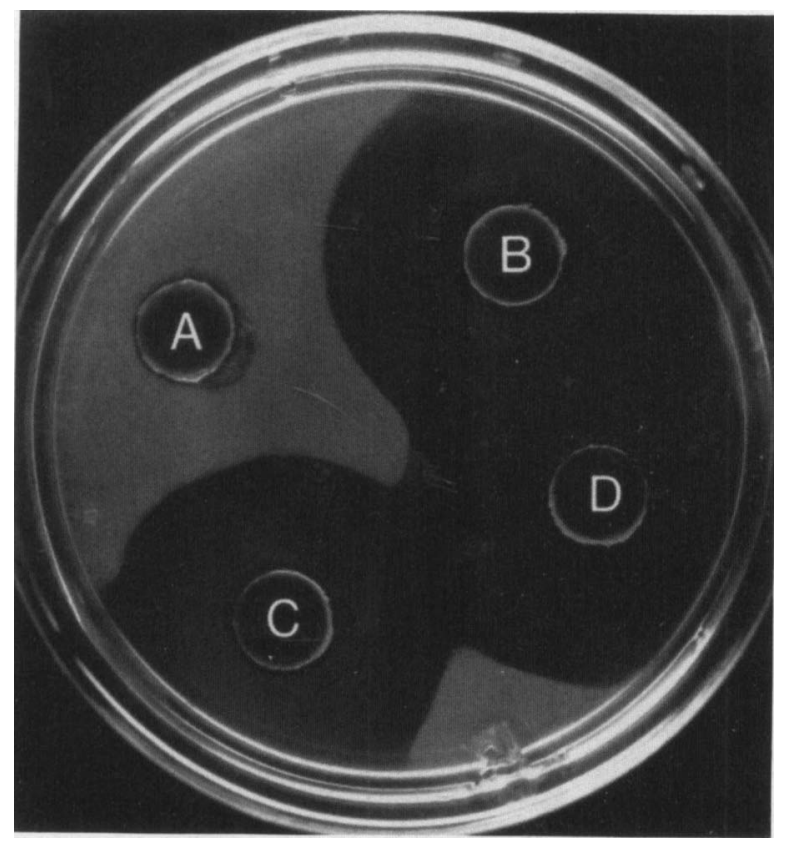

Fig. 3. Growth inhibition of spirochaete strain VS1 by MAbs F325 AC4 (B), F325 EB4 (C), F325 FC2 (D) and normal mouse serum (A) during anaerobic growth on agar. tensely labelled. The $16-\mathrm{kDa}$ antigen also appeared to be absent from strains B234 and P35/2.

\section{Slide agglutination and immunofluorescence labelling}

MAb AC4 agglutinated all strains of $S$. hyodysenteriae but not the non-pathogenic isolates B256, M1, PWS/A and 4/71 (table). S. hyodysenteriae strains B204, S75/1, P18A, VS1, MLC52/80 and LL6 were agglutinated strongly but strains B234, B169 and P35/2 were agglutinated only weakly. The agglutination observed with MAbs EB4 and FC2 was weaker than with MAb AC4.

In immunofluorescent studies, MAb AC4 labelled eight different strains of $S$. hyodysenteriae. However, it did not label strain P35/2 or the four non-pathogenic isolates examined. Variation was observed in the extent of fluorescent labelling displayed by the different $S$. hyodysenteriae strains.

\section{Growth inhibition tests (GIT)}

MAbs AC4, EB4 and FC2 inhibited the growth of $S$. hyodysenteriae strain VS1, whereas normal mouse serum had no effect (fig. 3). MAbs AC4 and EB4 inhibited the growth of all $S$. hyodysenteriae strains except P35/2. MAb FC2 did not inhibit the growth of strains B234, B169 or MLC52/80. None of the antibodies inhibited the growth of the non-pathogenic porcine spirochaetes B256, M1, PWS/A or 4/71.

\section{Immunogold labelling}

Since MAb AC4 agglutinated most strongly and 

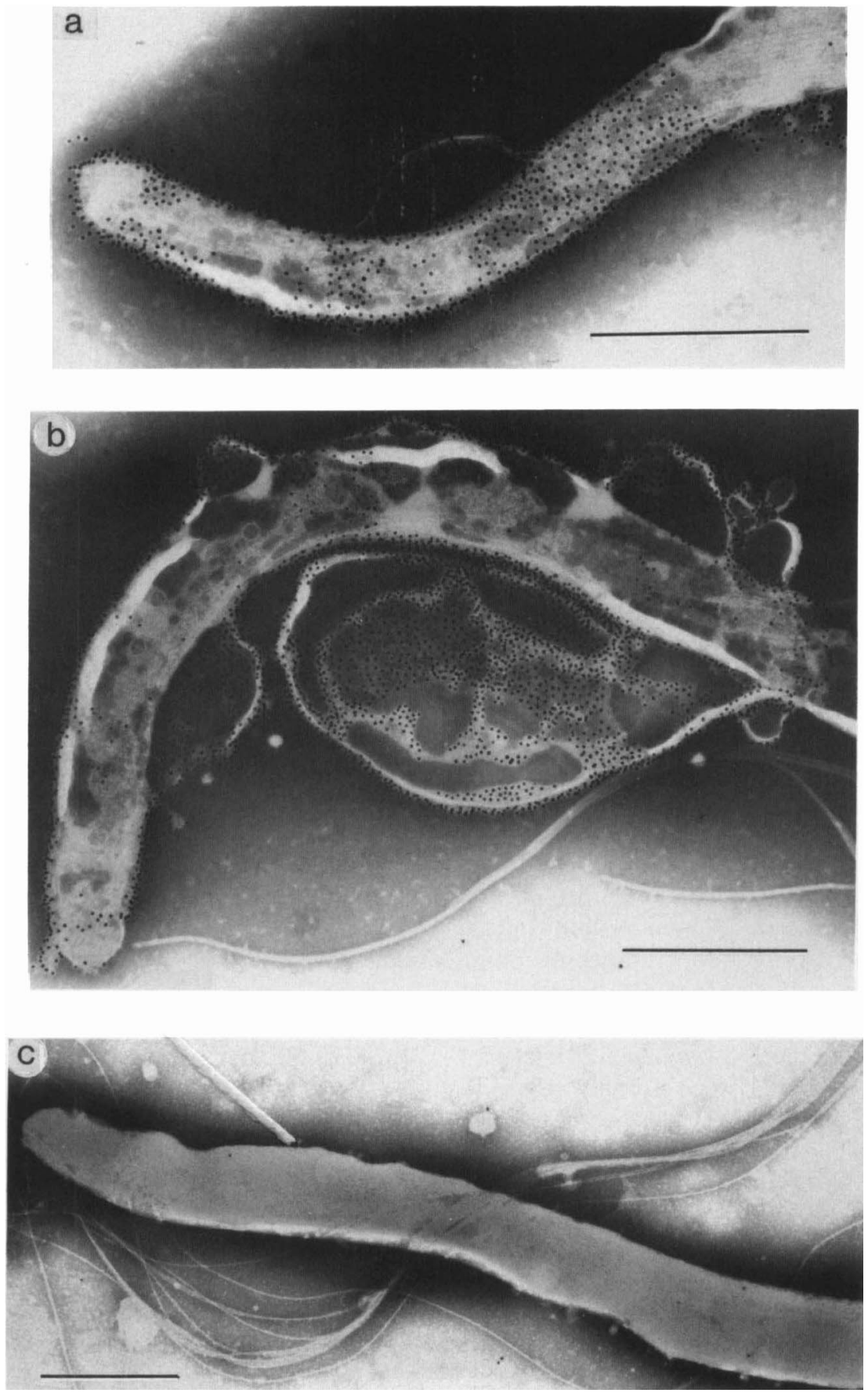

Fig. 4. Immunogold surface labelling of intact spirochaete cells from strains P18A (a), VSI (b) and PWS/A (c) by MAb F325 AC4. (Bar 0.5 $\mu \mathrm{m}$ ).

gave good immunofluorescence, it was used to label $S$. hyodysenteriae. The whole outer-envelope surface of strains P18A and VS1 was labelled extensively by $\mathrm{MAb}$ AC4, whereas there was no labelling of the nonpathogenic strain PWS/A (fig. 4). There was minimal disruption of the outer envelopes of the spirochaete cells during the immunogold treatment and negative staining. In general, the endoflagella remained within the periplasmic space, although where some disruption of the outer envelope had occurred, the exposed flagella did not bind any gold particles.

\section{Discussion}

S. hyodysenteriae strain VS1 was chosen for the production of MAbs because this isolate appeared to express the $16-\mathrm{kDa}$ antigen at a higher level than other strains of S. hyodysenteriae. ${ }^{16}$ The MAbs raised to the outer envelope of this strain recognised a $16-\mathrm{kDa}$ antigen that was common to most strains of $S$. hyodysenteriae but was absent from non-pathogenic porcine intestinal spirochaetes. There are several explanations for the apparent contradiction of these findings with previous investigations that have indicated that the $16-\mathrm{kDa}$ antigen was expressed by all strains of $S$. hyodysenteriae ${ }^{16}$ (a) the $16-\mathrm{kDa}$ antigen is 
not present, as previously suggested from studies with a polyclonal antiserum, on all strains of $S$. hyodysenteriae; (b) the epitopes recognised by the MAbs to strain VS1 are conserved in some strains or serotypes only; or (c) the expression of the antigen is poor in some strains or serotypes, e.g., B234, B169, MLC52/80 and P35/2. Strain P35/2 was not used in the investigation of Sellwood et al., ${ }^{16}$ but expression of the 16-kDa antigen was detected in strains B234, B169 and MLC52/80 by the polyclonal serum (B50) raised against outer envelopes of strain P18A. Therefore, the epitopes, which were recognised by the MAbs, may be absent from these strains. Also it is interesting to note that these strains are difficult to grow and there may be poor expression of this antigen when they are grown in vitro in less than optimum conditions.

As all three MAbs reacted in immunoblots, immunofluorescence and immunogold-labelling studies, agglutination and growth inhibition tests with most of the $S$. hyodysenteriae strains, the antigen must have structurally similar epitopes. Both immunofluorescence and immunogold-labelling studies demonstrated the surface exposure of the 16-kDa antigen in intact spirochaete cells. The absence of immunofluorescence on the cells of strain P35/2 and nonpathogenic spirochaetes was not unexpected in view of the apparent absence of this antigen in immunoblots against these isolates.

Growth inhibition studies showed differences between the MAbs. The lack of growth inhibition of strains B234, B169 and MLC52/80 by MAb FC2 may be due in part to those factors already identified or to the lower avidity of FC2 for the epitope, which may also be different to that recognised by the other MAbs. The binding efficacy may be affected by differences in the surface exposure of the respective epitopes or by in-vitro denaturation of antigenic structure. The observation that all the MAbs recognised the $16-\mathrm{kDa}$ antigen in its native form but that MAbs AC4 and FC2 reacted more strongly than EB4, following SDSPAGE procedures in Western blotting, suggests that only AC4 and FC2 can recognise a linear epitope.

\section{References}

1. Taylor DJ, Alexander, TJL. The production of dysentery in swine by feeding cultures containing a spirochaete. $\mathrm{Br} \mathrm{Vet}$ $J$ 1971; 127: lviii-lxi.

2. Stanton TB, Jensen NS, Casey TA, Tordoff LA, Dewhirst FE, Paster BJ. Reclassification of Treponema hyodysenteriae and Treponema innocens in a new genus, Serpula gen. nov., as Serpula hyodysenteriae comb. nov. and Serpula innocens comb. nov. Int J Syst Bacteriol 1991; 41: 50-58.

3. Stanton TB. Proposal to change the genus designation Serpula to Serpulina gen. nov. containing the species Serpulina hyodysenteriae comb. nov. and Serpulina innocens comb. nov. Int J Syst Bact 1992; 42: 189-190.

4. Fernie DS, Ripley PH, Walker PD. Swine dysentery: protection against experimental challenge following single dose parenteral immunisation with inactivated Treponema hyodysenteriae. Res Vet Sci 1983; 35: 217-221.

5. Joens LA, Nord NA, Kinyon JM, Egan IT. Enzyme-linked immunosorbent assay for detection of antibody to Tre-
The agglutinating properties of the MAbs may be responsible for the inhibition of growth of $S$. hyodysenteriae in vitro, since mouse antibodies of subclass IgG1 fix complement poorly. However, the mechanism of growth inhibition is far from clear. When $S$. hyodysenteriae is cultured in medium containing serum the organisms become coated with albumin that is resistant to removal by washing (unpublished observations). This may have contributed to the observed differences. Similar investigations with Treponema pallidum suggest that the spirochaetes may be protected, probably by a coat of host proteins, from the binding of antibody ${ }^{22}$ and its bactericidal activity. ${ }^{23}$

The observations presented here suggest that the generation in vivo of an antibody response to the 16$\mathrm{kDa}$ antigen, that appears to be highly antigenic, may reduce colonisation of the pig colon and contribute to the protection of pigs against swine dysentery. In contrast, the surface of $T$. pallidum has been considered to be immunologically inert. ${ }^{24}$ However, antigens, in particular lipoproteins, have been identified which may be potent immunogens. ${ }^{25-27}$ Similar observations have been made with Borrelia burgdorferi, the causative agent of Lyme disease, that also has immunodominant antigens, some of which are lipoproteins and may be located on the surface of the organism. ${ }^{28,29}$ Immunisation of mice with one of these antigens (OspA) has been shown to protect mice from subsequent challenge with $B$. burgdorferi. ${ }^{30}$ Evidence now exists that the $16-\mathrm{kDa}$ antigen of $S$. hyodysenteriae is also a lipoprotein. ${ }^{31}$ The development of MAbs to antigens of the outer envelope of $S$. hyodysenteriae should facilitate the characterisation of these antigens and elucidate their relative importance in the stimulation of a protective immune response to swine dysentery in pigs.

We are grateful to Mrs B. Jones for help in the preparation of MAbs and to Mrs P. Bland for guidance in the preparation of material for electronmicroscopy. The technical assistance of Miss F. Walton and the photography of Mr D. Hawkins and Miss C. Lonnen is gratefully acknowledged. We acknowledge the financial support of MAFF in this work. ponema hyodysenteriae antigens. J Clin Microbiol 1982; 15: 249-252.

6. Joens LA, DeYoung DW, Glock RD, Mapother ME, Cramer JD, Wilcox HE. Passive protection of segmented swine colonic loops against swine dysentery. Am J Vet Res 1985; 46: 2369-2371.

7. Olson LD. Clinical and pathological observations on the experimental passage of swine dysentery. Can J Comp Med $1974 ; 38: 7-13$.

8. Rees AS, Lysons RJ, Stokes CR, Bourne FJ. Antibody production by the pig colon during infection with Treponema hyodysenteriae. Res Vet Sci 1989; 47: 263-269.

9. Joens LA, Harris DL, Baum DH. Immunity to swine dysentery in recovered pigs. Am J Vet Res 1979; 40: 1352-1354.

10. Joens LA, Whipp SC, Glock RD, Nuessen ME. Serotype specific protection against Treponema hyodysenteriae infection in ligated colonic loops of pigs recovered from swine dysentery. Infect Immun 1983; 39: 460-462.

11. Nuessen ME, Joens LA. Serotype-specific opsonization of Treponema hyodysenteriae. Infect Immun 1982; 38: 1029-1032. 
12. Chatfield SN, Fernie DS, Penn C, Dougan G. Identification of the major antigens of Treponema hyodysenteriae and comparison with those of Treponema innocens. Infect Immun 1988; 56: 1070-1075.

13. Chatfield SN, Fernie DS, Beesley J, Penn C, Dougan G. Characterisation of the cell envelope of Treponema hyodysenteriae. FEMS Microbiol Lett 1988; 55: 303-308.

14. Joens LA, Marquez RB. Molecular characterization of proteins from porcine spirochetes. Infect Immun 1986; 54: 893-896.

15. Wannemuehler MJ, Hubbard RD, Greer JM. Characterization of the major outer membrane antigens of Treponema hyodysenteriae. Infect Immun 1988 56: 3032-3039.

16. Sellwood, R, Kent KA, Burrows, MR, Lysons RJ, Bland AP. Antibodies to a common outer envelope antigen of Treponema hyodysenteriae with antibacterial activity. $J$ Gen Microbiol 1989; 135: 2249-2257.

17. Kent KA, Sellwood, R, Lemcke RM, Burrows MR, Lysons RJ. Analysis of the axial filaments of Treponema hyodysenteriae by SDS-PAGE and immunoblotting. $J$ Gen Microbiol $1989 ; 135$ : 1625-1632.

18. Howard CJ, Parsons KR, Jones BV, Sopp P, Pocock DH. Two monoclonal antibodies (CC17, $\mathrm{CC} 29)$ recognizing an antigen (Bo5) on bovine $\mathrm{T}$ lymphocytes, analogous to human CD5. Vet Immunol Immunopathol 1988; 19: $127-139$.

19. Laemmli UK. Cleavage of structural proteins during the assembly of the head of bacteriophage T4. Nature 1970; 227: $680-685$.

20. Towbin H, Staehelin T, Gordon J. Electrophoretic transfer of proteins from polyacrylamide gels to nitrocellulose sheets: procedure and some applications. Proc Natl Acad Sci USA $1979 ; 76: 4350-4354$.

21. Lemcke RM, Burrows MR. A disc growth-inhibition test for differentiating Treponema hyodysenteriae from other intestinal spirochaetes. Vet Rec 1979; 104: 548-551.
22. Penn CW. Avoidance of host defences by Treponema pallidum in situ and on extraction from infected rabbit testes. $J$ Gen Microbiol 1981; 126: 69-75.

23. Stamm LV, Hodinka RL, Wyrick PB, Bassford PJ. Changes in the cell surface properties of Treponema pallidum that occur during in vitro incubation of freshly extracted organisms. Infect Immun 1987; 55: 2255-2261.

24. Radolf JD, Norgard MV, Schulz WW. Outer membrane ultrastructure explains the limited antigenicity of virulent Treponema pallidum. Proc Natl Acad Sci USA 1989; 86 2051-2055.

25. Radolf JD, Chamberlain NR, Clausell A, Norgard MV. Identification and localization of integral membrane proteins of virulent Treponema pallidum subsp. pallidum by phase partitioning with the nonionic detergent Triton $\mathrm{X}$ 114. Infect Immun 1988; 56: 490-498.

26. Chamberlain NR, Brandt ME, Erwin AL, Radolf JD, Norgard MV. Major integral membrane protein immunogens of Treponema pallidum are proteolipids. Infect Immun 1989; 57: 2872-2877.

27. Swancutt MA, Radolf JD, Norgard MV. The 34-kilodalton membrane immunogen of Treponema pallidum is a lipoprotein. Infect Immun 1990; 58: 384-392.

28. Barbour AG, Tessier SL, Hayes SF. Variation in a major surface protein of Lyme disease spirochaetes. Infect Immun 1984; 45: 94-100.

29. Brandt ME, Riley BS, Radolf JD, Norgard MV. Immunogenic integral membrane proteins of Borrelia burgdorferi are lipoproteins. Infect Immun 1990; 58: 983-991.

30. Fikrig E, Barthold SW, Kantor FS, Flavell RA. Protection of mice against Lyme disease agent by immunizing with recombinant OspA. Science 1990; 250: 553-556.

31. Thomas W, Sellwood R, Lysons RJ. A 16-kDa lipoprotein of the outer membrane of Serpulina (Treponema) hyodysenteriae. Infect Immun 1992; in press. 